Jurnal Ilmu Dan Teknologi Kesehatan

Vol 6, No 1, September 2018,

ISSN: 2338-9095 (Print)

ISSN: 2338-9109 (online)

\title{
Bakteri Asam Laktat Lactobacillus Plantarum C410LI dan Lactobacillus Rossiae LS6 yang Diisolasi dari Lemea Rejang terhadap Suhu, pH dan Garam Empedu Berpotensi sebagai Prebiotik
}

\author{
Yenni Okfrianti ${ }^{1}$, Darwis ${ }^{2}$, Ayu Pravita $^{3}$ \\ Poltekkes Kemenkes Bengkulu \\ yenni79okfrianti@gmail.com
}

\begin{abstract}
Artikel history
Dikirim, Jun $22^{\text {nd }}, 2018$

Ditinjau, Aug 21 $1^{\text {st }}, 2018$

Diterima, Aug $28^{\text {th }}, 2018$
\end{abstract}

\begin{abstract}
Based on previous research it was found that lemea (traditional food rejang) was proven to contain 2 types of lactic acid bacteria (BAL) namely L.aplantarum C410L1 and L. crossiae LS6 which could be probiotic and beneficial for health. The development of lemea as a potential probiotic must be proven its resistance to bile acids and salts as an indication of being able to survive in the gastrointestinal tract. This study aims to determine the resistance of BAL isolated from lemea against low $\mathrm{pH}$, bile acids, and temperature. This research is an experimental study with all research units controlled. Analysis of BAL resistance to high temperatures, low $\mathrm{pH}$, and bile salts was carried out in the Bengkulu Polytechnic Health Polytechnic laboratory. The total BAL colonies increased at $49^{\circ} \mathrm{C}$ and decreased at $64^{\circ} \mathrm{C}$. The increase in the total number of BAL colonies within 0-30 hours occurred at $\mathrm{pH} 5$ and $\mathrm{pH}$ 6. There was no increase or decrease in the total number of BAL colonies in salts $0.30 \%$, $0.60 \%$, and $0.90 \%$. The diisolate lactic acid (BAL) bacteria from lemea have a temperature resistance of $42^{\circ} \mathrm{C}$ to $64^{\circ} \mathrm{C}$, $\mathrm{pH} 2$ to $\mathrm{pH}$, have a salt resistance concentration of $0.30 \%$ to $0.90 \%$. Lactic acid bacteria (BAL) which are diisolate from lemea have the potential as probiotics.
\end{abstract}

Keywords: salt, $p H$, temperature, time, lactic acid bacteria

\begin{abstract}
ABSTRAK
Berdasarkan penelitian sebelumnya diketahui bahwa lemea (makanan tradisional rejang) terbukti mengandung 2 jenis bakteri asam laktat (BAL) yaitu L.aplantarum C410L1 dan L.rossiae LS6 yang dapat bersifat probiotik dan bermanfaat untuk kesehatan. Pengembangan lemea sebagai probiotik potensial wajib dibuktikan ketahanannya terhadap asam dan garam empedu sebagai indikasi mampu bertahan hidup dalam saluran cerna. Penelitian ini bertujuan untuk mengetahui ketahanan BAL yang diisolasi dari lemea terhadap $\mathrm{pH}$ rendah, asam empedu, dan suhu. Penelitian ini merupakan penelitian eksperimen dengan semua unit penelitian dikontrol. Analisis ketahanan BAL terhadap suhu tinggi, $\mathrm{pH}$ rendah, dan garam
\end{abstract}


empedu dilakukan di laboratorium Mikrobiologi Poltekkes Kemenkes Bengkulu. Total koloni BAL mengalami peningkatan pada suhu $49^{\circ} \mathrm{C}$ dan penurunan pada suhu $64^{\circ} \mathrm{C}$. Peningkatan jumlah total koloni BAL dalam waktu 0-30 jam terjadi pada $\mathrm{pH} 5$ dan $\mathrm{pH}$ 6. Tidak terjadi peningkatan atau penurunan jumlah total koloni BAL pada garam $0,30 \%, 0,60 \%$, maupun $0,90 \%$. Bakteri asam laktat (BAL) yang diisolat dari lemea memiliki ketahanan terhadap suhu $42^{\circ} \mathrm{C}$ sampai $64^{\circ} \mathrm{C}, \mathrm{pH} 2$ sampai $\mathrm{pH} 7$, memiliki ketahanan terhadap garam konsentasi $0,30 \%$ sampai $0,90 \%$. Bakteri asam laktat (BAL) yang diisolat dari lemea memiliki potensi sebagai probiotik.

Kata Kunci: garam, pH, suhu, waktu, bakteri asam laktat

\section{PENDAHULUAN}

Bakteri Asam Laktat (BAL) adalah sejenis bakteri gram positif, tidak menghasilkan spora, berbentuk bulat atau batang dan memproduksi asam laktat sebagai produk akhir metabolik utama selama proses fermentasi (Ramesh, 2015). Bakteri asam laktat dapat berfungsi sebagai bakteriosin yang sangat bermanfaat bagi kesehatan. Bakteriosin adalah komponen ekstraseluler berupa peptide atau senyawa yang berupa protein antimikroba yang memperlihatkan suatu respon berlawanan terhadap bakteri tertentu (Jagadesswari, 2010). Bakteri asam laktat juga disebut probiotik (Emmawati, 2015).

Probiotik yaitu mikroorganisme hidup yang memberi manfaat kesehatan terhadap inangnya apabila dikonsumsi dalam jumlah yang cukup. Prinsip kerja probiotik yaitu dengan memafaatkan kemampuan organism tersebut dalam menguraikan rantai panjang karbohidrat, protein, dan lemak. Kemampuan ini diperoleh karena adanya enzim-enzim khusus yang dimiliki oleh mikroorganisme untuk memecah ikatan dari molekul kompleks menjadi molekul sederhana sehingga mempermudah penyerapan oleh saluran pencernaan manusia (Williams, 2010).

Bakteri asam laktat (BAL) sebagai sumber probiotik mengandung asam amino pendek yang mampu menurunkan tekanan darah, meningkatkan kekebalan tubuh, dan menghambat kerja enzim pembentuk kolesterol sehingga menurunkan kolesterol tubuh (Beltrán-Barrientos et al., 2016). Manfaat lain adalah kandungan senyawa dalam bakteri asam laktat juga dapat mencegah terjadinya kanker. Bakteri asam laktat banyak terdapat pada produk susu fermentasi (dadih, yoghurt), produk asinan sayur buah, dan produk-produk fermentasi lainnya (Ramesh, 2015).

Manfaat yang bisa diperoleh dari kebiasaan mengkonsumsi probiotik yaitu mampu meningkatkan pertahanan imunitas 
nonspesifik. Probiotik dari jenis Lactobaccillus casei dan Lactobacilus bulgaricus diketahui dapat meningkatkan produksi makrofag dan mengaktifkan fagosit baik penelitian pada manusia maupun pada tikus percobaan. Proses fagositosis merupakan respon awal dari sistem pertahanan tubuh sebelum tubuh membentuk antibodi. Fagosit akan menyingkirkan agen-agen toksik yang masuk ke dalam tubuh sehingga dapat menurunkan tekanan darah dan membantu menurunkan kolesterol (Widiyaningsih, 2011).

Bakteri asam laktat merupakan fastidious organism, tumbuh dengan baik pada medium kompleks. Asam laktat diproduksi sebagai metabolit primer, sehingga termasuk growth-associated product. Produksi Bakteri asam laktat mempunyai hubungan linier dengan laju pertumbuhan. Hal ini menunjukkan bahwa untuk dapat dikatakan probiotik pertumbuhan bakteri asam laktat sangat dipengaruhi oleh komposisi media pertumbuhan dan faktor lingkungannya (Williams, 2010).

Faktor yang dapat mempengaruhi pertumbuhan dan produksi asam laktat adalah $\mathrm{pH}$, suhu dan garam empedu. Setiap spesies bahkan strain dapat memiliki nilai $\mathrm{pH}$ dan suhu terbaik yang berbeda untuk pertumbuhan dan produksi asam laktat.
Hal ini ditunjukkan oleh penelitian yang sudah dilakukan oleh Abdel-Rahman et al (2013) dan Aghababaie et al (2015) pada penelitian ini yakni terdapat pengaruh $\mathrm{pH}$, suhu, dan salisitas terhadap pertumbuhan dan produksi asam laktat 3 jenis isolat bakteri asam laktat pada bahan makanan fermentasi.

Makanan sejenis bekasam dapat ditemukan di Provinsi Bengkulu yakni Lemea. Lemea adalah makanan fermentasi tradisional Suku Rejang yang terbuat dari campuran ikan air tawar dan rebung yang dicacah, selanjutnya difermentasi selama 3-4 hari pada suhu $25,17^{\circ} \mathrm{C}$. Lemea mengandung kadar air yang sangat tinggi yakni sebesar $90,87 \%$ dan rasa asam yang khas dengan pH 4,55 (Nurutami et al., 2014). Selain itu juga lemea diketahui mengandung bakteri genus Pediococcus (Rianti et al., 2014) dengan koloni bakteri sebanyak $118,67 \times 10$ ${ }^{4}$ koloni /gram (Nurutami et al, 2014).

Pada penelitian tahap 1 yang sudah dilakukan sebelumnya diketahui lemea yang sudah difermentasikan dengan bahan dasar ikan betok mengandung BAL sebanyak $1,7 \times 10^{8}$ koloni $/ g$ dengan diperoleh jenis bakterinya yakni Lactobacillus plantarum C410L1 dan Lactobacillus rosiiae LS6. Penelitian sebelumnya yakni untuk membuktikan lemea memiliki potensi sebagai makanan 
fermentasi asli Suku Rejang sebagai penghasil angiotensin converting enzyme anti hipertensi. Namun pada penelitian ini, belum diteliti secara in vitro untuk membuktikan apakah lemea mampu menjadi probiotik. Sehingga perlu diteliti ketahanan BAL pada lemea terhadap suhu, $\mathrm{pH}$ rendah dan garam empedu. Beberapa spesies BAL merupakan probiotik yang baik karena dapat bertahan melewati $\mathrm{pH}$ lambung yang rendah dan menempel atau melakukan kolonisasi usus. Akibatnya, bakteri jahat di usus akan berkurang karena kalah bersaing dengan BAL.

\section{METODE}

Bahan yang digunakan dalam peneitian ini adalah bakteri asam laktat yang diisolat dari produk Lemea (Makanan khas Rejang Lebong). Berikut tahapan penelitian yang dilakukan:

Tahap I : (Ketahanan BAL terhadap Suhu Tinggi)

Sebanyak $1 \mathrm{ml}\left(10^{6} \mathrm{CFU} / \mathrm{ml}\right)$ kultur yang telah disegarkan dalam BHI (Brain Hearth Broth) selama 24 jam, diatur inkubasinya selama 10, 20 dan 30 menit pada suhu yang meningkat yaitu $37^{\circ} \mathrm{C}, 40^{\circ} \mathrm{C}, 43^{\circ} \mathrm{C}$, $46^{0} \mathrm{C}, 49^{0} \mathrm{C}, 52^{0} \mathrm{C}, 55^{0} \mathrm{C}, 58^{0} \mathrm{C}, 61^{0} \mathrm{C}, 64^{0} \mathrm{C}$, $67^{\circ} \mathrm{C}, 70^{\circ} \mathrm{C}, 73^{\circ} \mathrm{C}, 76^{\circ} \mathrm{C}, 79^{\circ} \mathrm{C}$. Selanjutnya dilakukan perhitungan jumlah BAL dengan menggunakan metode hitungan cawan pada media PCA (Plate Count Agar). Semakin banyak penurunan jumlah sel setelah inkubasi maka semakin tidak tahan bakteri tersebut terhadap suhu tinggi (Harmayani dkk, 2009).

Tahap II (Uji Ketahanan BAL terhadap pH Rendah)

Sebanyak $1 \mathrm{ml}\left(10^{6} \mathrm{CFU} / \mathrm{ml}\right)$ kultur yang telah disegarkan dalam BHI (Brain Hearth Broth) selama 24 jam, diatur inkubasinya selama 0,5 dan 30 jam pada $\mathrm{pH}$ yang meningkat yaitu 2, 3, 4, 5, 6, 7 . Selanjutnya dilakukan perhitungan jumlah BAL dengan menggunakan metode hitungan cawan pada media PCA (Plate Count Agar). Semakin banyak penurunan jumlah sel setelah inkubasi maka semakin tidak tahan bakteri tersebut terhadap $\mathrm{pH}$ rendah.

Tahap III (Ketahanan BAL pada Garam Empedu)

Sebanyak $1 \mathrm{ml}$ ( $10{ }^{6} \mathrm{CFU} / \mathrm{ml}$ ) kultur yang telah disegarkan dalam BHI (Brain Hearth Broth) selama 24 Jam, diatur diinkubasi selama 24 jam pada garam $\mathrm{NaCl}$ dengan konsentrasi $0 \%, 0.3 \%, 0.6 \%$, dan $0.9 \%$. Selanjutnya dilakukan perhitungan jumlah BAL dengan menggunakan metode hitungan cawan pada media PCA (Plate Count Agar). Semakin banyak penurunan 
53 Jurnal Ilmu dan Teknologi Kesehatan, Vol 6 Nomor 1, September 2018, hlm : 49 - 58

jumlah sel setelah inkubasi maka semakin tidak tahan bakteri tersebut terhadap $\mathrm{NaCl}$.

\section{HASIL DAN PEMBAHASAN}

1. Identifikasi ketahanan Bakteri Asam Laktat (BAL) yang diisolasi dari Lemea terhadap suhu dan waktu
Berdasarkan hasil penelitian diketahui bahwa adanya peningkatan dan penurunan jumlah koloni BAL pada suhu $49^{\circ} \mathrm{C}$ sampai $64^{\circ} \mathrm{C}$. Pada suhu $49^{\circ} \mathrm{C}$ terjadi peningkatan total koloni BAL dan terjadi penurunan pada suhu $64^{\circ} \mathrm{C}$. Penjelasan dapat dilihat pada Gambar 1.

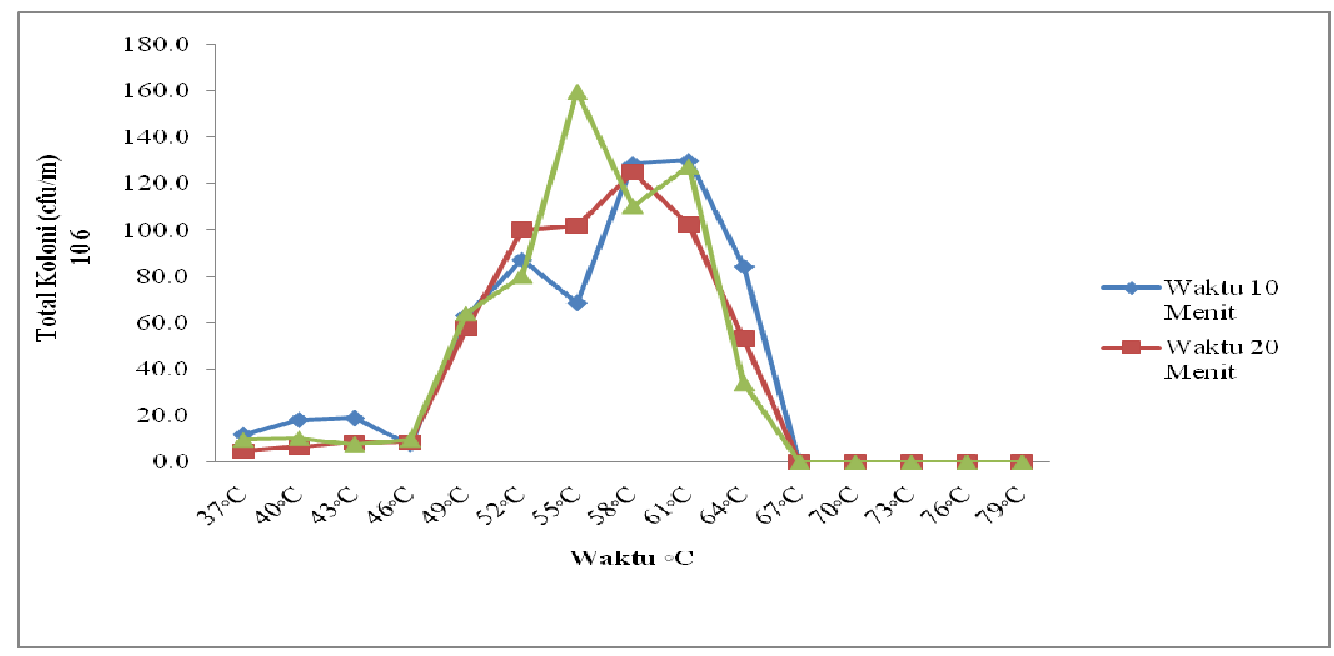

Gambar 1. Total Koloni (cfu/ml) $10{ }^{6}$ pada Suhu dan Waktu yang Berbeda

Hal ini menunjukkan suhu berpengaruh terhadap pertumbuhan sel. Menurut Elias et al (2014) suhu merupakan faktor fisik yang berpengaruh pada laju pertumbuhan melalui pengaruhnya diantaranya terhadap reaksi kimia dan stabilitas struktur molekul protein. Reaksi kimia akan meningkat dengan meningkatnya suhu karena peningkatan suhu menyebabkan peningkatan energi kinetik reaktan. Pertumbuhan pada hakekatnya adalah hasil metabolisme, suatu reaksi kimia terarah yang berlangsung di dalam sel yang dikatalisis oleh enzim. Maka peningkatan suhu akan menyebabkan peningkatan pertumbuhan hingga suatu saat peningkatan suhu tidak diikuti dengan meningkatnya pertumbuhan.

Hal ini berkaitan dengan pengaruh suhu terhadap stabilitas konsformasi struktur protein enzim. Selain itu juga diketahui bahwa pada proses metabolisme sel didukung oleh penyediaan nutrisi yang berasal dari luar sel. Proses yang terkait dengan uptake nutrien dengan suhu adalah bahwa molekul-molekul yang berukuran besar harus dihidrolisis terlebih di luar sel. Proses ini dikatalisis oleh enzim ekstraseluler yang aktivitasnya juga dipengaruhi oleh suhu. Selain itu ada 
banyak protein membran dan protein dinding sel yang berperan dalam proses uptake nutrient yang secara fungsional juga dipengaruhi oleh suhu terutama terkait dengan stabilitas strukturalnya (Subagiyo et al., 2015). Pengaruh suhu terhadap uptake nutrient terjadi melalui mekanisme perubahan affinitas mikroorganisme terhadap nutrient. Perubahan ini terjadi karena pengaruh perubahan suhu terhadap karakterisitik lipid penyusun membran sel, terutama fluiditas membran, dan sistem energetika transport aktif yang juga terdapat pada sistem membran sehingga akan menyebabkan gangguan pada transport aktif.

2. Identifikasi ketahanan Bakteri Asam Laktat (BAL) yang diisolasi dari Lemea terhadap $\mathrm{pH}$ dan waktu

Hasil penelitian diketahui bahwa adanya penurunan jumlah total koloni BAL dalam waktu 5 jam pada pH 2, pH 4, pH 6 . Penurunan total koloni BAL paling banyak terjadi pada $\mathrm{pH}$ 2. Peningkatan jumlah total koloni BAL dalam waktu 0-30 jam terjadi pada $\mathrm{pH} 5$ dan $\mathrm{pH}$ 6. Peningkatan paling banyak terjadi pada $\mathrm{pH} 6$ dapat dilihat pada Gambar 2 berikut ini.

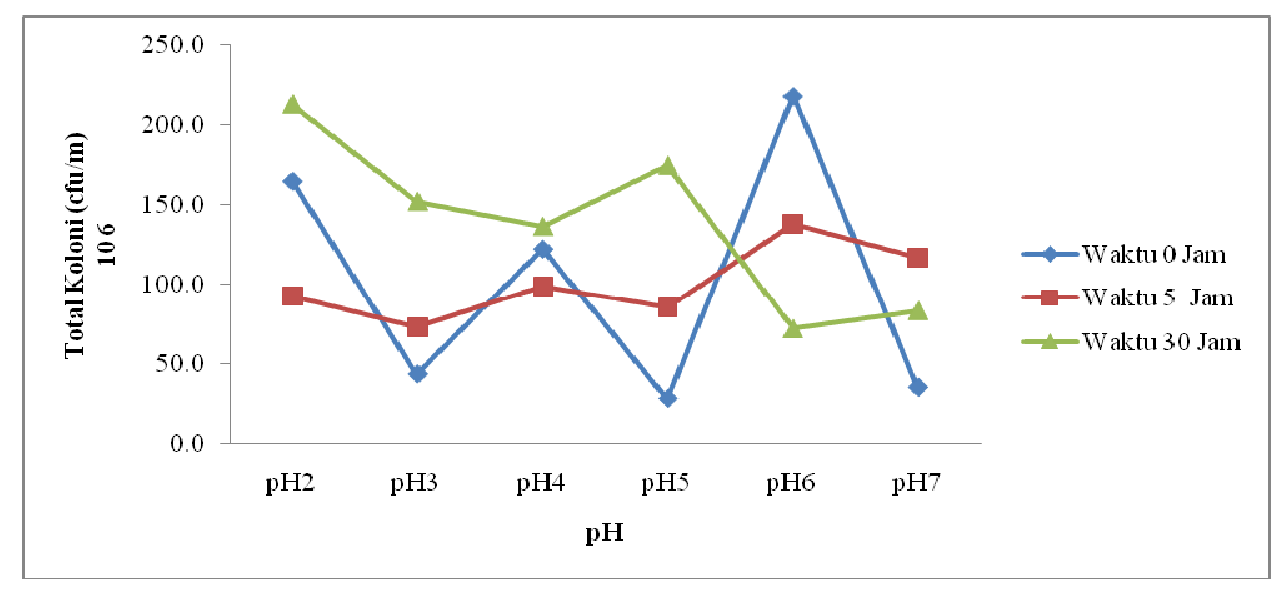

Gambar 2. Total Koloni (cfu/ml) $10{ }^{6}$ pada $\mathrm{pH}$ dan Waktu yang Berbeda

Penelitian ini sejalan dengan penelitian yang dilakukan oleh Subagiyo et al. (2015) yang menunjukkan hasil nilai laju pertumbuhan tertinggi dari tiga isolat uji terjadi pada suhu, $\mathrm{pH}$ awal dan salinitas yang berbeda. Isolat L12 tumbuh optimum pada suhu $30^{\circ} \mathrm{C}$, pH awal 6 dan salinitas $0,75 \%$. Isolat L14 tumbuh optimum pada suhu $30^{\circ} \mathrm{C}$, pH awal 6 dan salinitas $1.5 \%$. Isolat L21 tumbuh optimum pada suhu $30^{\circ} \mathrm{C}, \mathrm{pH}$ awal 6 dan salinitas $1.5 \%$. 
Nagarjun (2015) melaporkan $\mathrm{pH}$ awal optimum untuk produksi asam laktat oleh bakteri Lactobacillus amylovorus NRRL B- 4542 adalah 8,5. Pengaruh $\mathrm{pH}$ terhadap pertumbuhan dan produksi asam laktat terjadi diantaranya melalui 2 mekanisme yaitu (1) Penurunan nilai $\mathrm{pH}$ akibat akumulasi asam organik mengubah keadaan fisiologis sel. Pengasaman sitoplasmik menyebabkan penghambatan aktivitas enzim, akibatnya fluks katabolik melalui glikolisis berkurang sehingga laju sintesis energi biokimia menurun. Penurunan produksi energi bersamaan dengan peningkatan penggunaan energi untuk mengatasi pengasaman sitoplasma menyebabkan energi untuk sintesis biomassa menjadi terbatas. Dalam kondisi ini, laju pertumbuhan spesifik menurun secara progresif, dan pertumbuhan akhirnya berhenti. Respon seluler terhadap fenomena ini adalah mempertahankan mRNA gen-gen katabolik pada tingkat yang signifikan, melalui transkripsi gen dan meningkatkan stabilitas transkrip. Jadi translasi dipertahankan dan konsentrasi intraseluler enzim-enzim tertentu ditingkatkan, sebagai kompensasi secara parsial terhadap aktivitas penghambatan akibat penurunan $\mathrm{pH}$ (Even et al., 2002) (2) Stres asam laktat mengubah profil ekspresi gen. Hasil penelitian Xie et al (2004) menunjukkan terjadi perubahan ekspresi 50 gen akibat stress asam laktat, yaitu 24 gen yang diinduksi dan 26 gen yang lain ditekan.

3. Identifikasi Ketahanan Bakteri Asam Laktat (BAL ) yang Diisolasi dari Lemea terhadap Garam Empedu Hasil penelitian diketahui bahwa BAL tahan terhadap garam, tidak ada peningkatan atau penurunan jumlah total koloni BAL pada garam 0,30\%, 0,60\%, maupun $0,90 \%$ dapat dilihat pada Gambar 3.

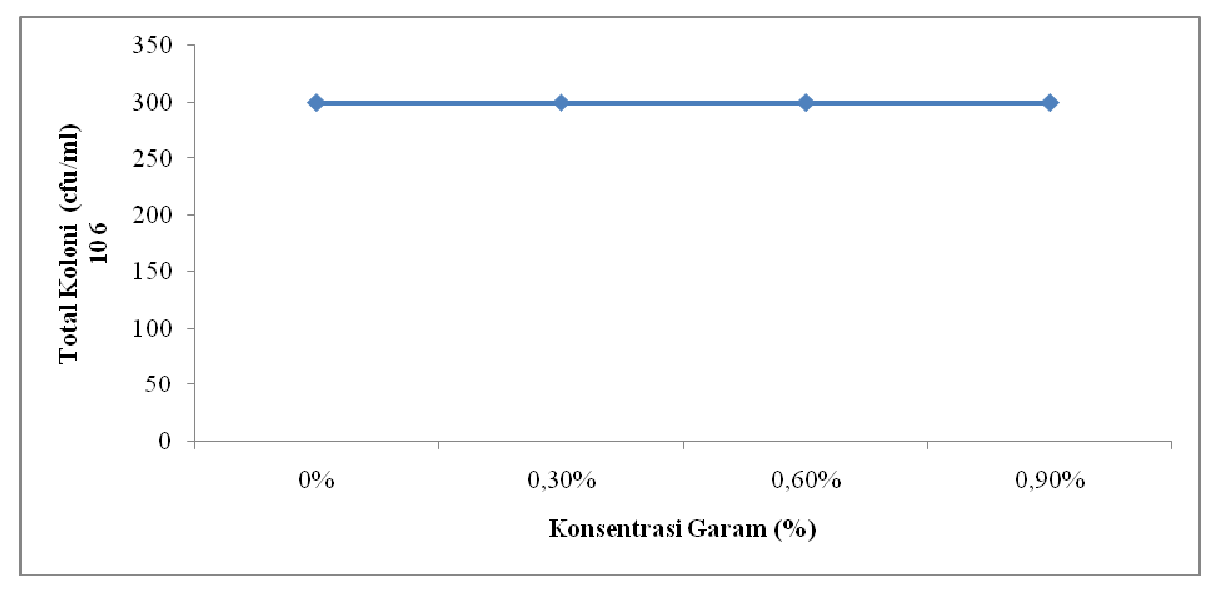

Gambar 3. Total Koloni (cfu/ml) $10{ }^{6}$ pada Konsentrasi Garam yang Berbeda 
Pada penelitian tahap 1 yang sudah dilakukan sebelumnya diketahui lemea yang sudah difermentasikan dengan bahan dasar ikan betok mengandung BAL sebanyak $1.7 \times \quad 10^{8}$ koloni $/ g$ dengan diperoleh jenis bakterinya yakni Lactobacillus plantarum C410L1 dan Lactobacillus rosiiae LS6.

Penelitian yang dilakukan oleh Emmawati et al (2015) menunjukkan bahwa bakteri yang tahan terhadap garam $0,50 \%$ dan suhu $\mathrm{pH} 2$ berpotensi sebagai probiotik. Penelitian ini sejalan dengan penelitian yang dilakukan oleh Sunaryanto dan Marwoto (2012) telah diperoleh lima isolat Lactobacillus DH1, DH2, DH3, DH3, dan DH5 sebagai kandidat probiotik yang diisolasi dari dadih susu kerbau. Hasil identifikasi secara fenotip dan secara molekuler menggunakan 16S rRNA, isolat DH2 teridentifikasi sebagai Lactobacillus plantarum dan memiliki karakteristik yang dapat digunakan sebagai kandidat probiotik. Isolat $\mathrm{DH} 2$ mampu bertahan hidup sampai dengan $\mathrm{pH} 2$, konsentrasi garam empedu sampai dengan $0,5 \%(\mathrm{~b} / \mathrm{v})$.

Penelitian lain oleh Adawiyah et al (2015) menunjukkan bahwa Bakteri Asam Laktat isolat susu sapi asli dangke L. fermentum dan L. acidophillus memiliki ketahanan garam empedu. Ketahanan Bakteri Asam
Laktat (BAL) terhadap garam empedu merupakan suatu karakteristik yang penting, karena akan berpengaruh pada aktivitas BAL dalam saluran pencernaan, terutama saluran usus bagian atas tempat empedu disekresikan. Empedu bersifat sebagai senyawa aktif permukaan. Sifat ini yang menyebabkan aktifnya enzim lipolitik yang disekresikan pankreas. Enzim lipolitik bereaksi dengan asam lemak pada membran sitoplasma BAL, sehingga mengakibatkan perubahan struktur membran dan sifat permeabilitasnya. Keragaman struktur asam lemak pada membran sitoplasma bakteri menyebabkan perbedaan permeabilitas dan karakteristiknya sehingga mungkin mempengaruhi ketahanannya terhadap garam empedu.

\section{SIMPULAN}

Bakteri asam laktat (BAL) yang diisolat dari lemea memiliki ketahanan terhadap suhu $42^{\circ} \mathrm{C}$ sampai $64^{\circ} \mathrm{C}$. Bakteri asam laktat (BAL) yang diisolat dari lemea memiliki ketahanan terhadap $\mathrm{pH} 2$ sampai $\mathrm{pH}$ 7. Bakteri asam laktat (BAL) yang diisolat dari lemea memiliki ketahanan terhadap garam konsentasi $0,30 \%$ sampai $0,90 \%$. 


\section{DAFTAR RUJUKAN}

Abdel-Rahman MA, Tashiro Y, Sonomoto K. 2013. Recent advances in lactic acid production by microbial fermentation processes. Biotechnology Advances 31: $\quad 877-902 . \quad$ DOI: 10.1016/j.biotechadv.2013.04.002.

Adawiyah SR, Hafsan, Nur FMHM. 2015. Ketahanan bakteri asam laktat asal dangke terhadap garam empedu sebagai kandidat probiotik. Fakultas Sains dan Teknologi UIN 164-173.

Aghababaie M, Khanahmadi M, Beheshti M. 2015. Developing a kinetic model for co-culture of yogurt starter bacteria growth in $\mathrm{pH}$ controlled batch fermentation. Journal of Food Engineering 166: 72-79. DOI: 10.1016/j.jfoodeng.2015.05.013.

Beltrán-Barrientos LM, Hernandez A, Mendoza M, Torres-Llanez M. 2016. Invited review: Fermented milk as antihypertensive functional food. Journal of Dairy Science 99: 40994110. DOI: $10.3168 /$ jds.2015-10054.

Elias M, Wieczorek G, Rosenne S. 2014. The universality of enzymatic ratetemperature dependency. Trends in Biochemical Sciences 39: 1-7. DOI: 10.1016/j.tibs.2013.11.001.

Emmawati A, Laksmi B, Nuraida L. 2015. Characterization of Lactic Acid Bacteria Isolates from Mandai Function as Probiotic. Jurnal Agritech 35: 146.

DOI: 10.22146/agritech.9400.

Even S, Lindley N, Loubiere P. 2002. Dynamic response of catabolic pathways to autoacidification in Lactococcus lactis: Transcript profiling and stability in relation to metabolic and energetic constraints.
Molecular Microbiology 45: 11431152. DOI: $\quad 10.1046 / \mathrm{j} .1365-$ 2958.2002.03086.x.

Harmayani E, Ngatirah, Rahayu E. 2009. Ketahanan dan Viabilitas Probiotik Bakteri Asam Laktat Selama Proses Pembuatan Kultur Kering dengan Metode Freeze dan Spray Drying. Jurnal Teknol dan Industri Pangan 7: 126-132.

Jagadesswari S, Vidya P. 2010. Isolation and Characterization of Bacteriocin Producing Lactobacillus sp. From Traditional Fermented Food. Electronic Journal of Environmental Agricultural and Food Chemistry 9: 575-581

Nagarjun PA. 2015. Parametric optimization of lactic acid production and its scale up using free and immobilized cells of Lactobacillus amylovorus NRRL B- 4542. International Journal Bioscience 3: 159-168. DOI: 10.18782/23207051.2124

Ramesh C, Ray DM. 2015. Food Biology Series. 108-109. CRC Press, Boca Raton, Florida.

Subagiyo S, Margino S, Triyanto, Setyati WA. 2015. Effects of $\mathrm{pH}$, temperature and salinity in growth and organic acid production of lactic acid bacteria isolated from penaeid shrimp intestine. Indonesian Journal of Marine Sciences 20: 187. DOI: 10.14710/ik.ijms.20.4.187-194.

Sunaryanto R, Marwoto B. 2012. Isolasi, identifikasi, dan karakterisasi bakteri asam laktat dari dadih susu kerbau. Jurnal Sains dan Teknologi Indonesia 14: 228-233.

Widiyaningsih EN. 2011. Peran Probiotik 
Yenni O, Darwis, dan Ayu P, Bakteri Asam Laktat Lactobacillus Plantarum C410LI dan

Untuk Kesehatan. Jurnal Kesehatan 4: 14-20.

Williams NT. 2010. Probiotics. American Journal Of Health-System Pharmacy: AJHP: Official Journal Of The American Society Of Health-System Pharmacists 67: 449-458. DOI: 10.2146/ajhp090168.
Xie Y, Chou L, Cutler A. 2004. DNA macroarray profiling of Lactococcus lactis subsp. lactis IL1403 gene expression during environmental stresses. Applied and Environmental Microbiology 70: 6738-6747. DOI: 10.1128/AEM.70.11.6738-6747.2004. 